OPEN ACCESS

Edited by:

Heriberto Rodriguez-Martinez, Linköping University, Sweden

Reviewed by:

Maria Alejandra Stornelli, National University of La Plata,

Argentina

Martin G. Maquivar Washington State University,

United States

${ }^{*}$ Correspondence:

Carolina Balao da Silva

carolina.silva@ipportalegre.pt

Specialty section: This article was submitted to Animal Reproduction Theriogenology,

a section of the journal Frontiers in Veterinary Science

Received: 26 November 2018 Accepted: 27 February 2019 Published: 22 March 2019

Citation:

Balao da Silva C, Gómez Gordo L, Cuesta Gerveno JM, Ortega-Ferrusola C, Martín-Muñoz P, Duque Carrasco FJ, Parejo C and Peña Vega F (2019) A Rare Case of a Primary Unilateral Low-Grade Paratesticular Leiomyosarcoma in a 2 Years Old

Dog. Front. Vet. Sci. 6:83. doi: 10.3389/fvets.2019.00083

\section{A Rare Case of a Primary Unilateral Low-Grade Paratesticular Leiomyosarcoma in a 2 Years Old Dog}

\author{
Carolina Balao da Silva ${ }^{1 *}$, Luis Gómez Gordo², Jesús María Cuesta Gerveno², \\ Cristina Ortega-Ferrusola ${ }^{3}$, Patricia Martín-Muñoz ${ }^{3}$, Francisco Javier Duque Carrasco ${ }^{4}$, \\ Carlos Parejo ${ }^{5}$ and Fernando Peña Vega ${ }^{3}$ \\ ${ }^{1}$ VALORIZA, Polytechnic Institute of Portalegre, Superior Agrarian School of Elvas, Elvas, Portugal, ${ }^{2}$ Pathological Anatomy \\ Service, Veterinary Teaching Hospital, Caceres, Spain, ${ }^{3}$ Laboratory of Equine Reproduction and Equine Spermatology, \\ Veterinary Teaching Hospital, Caceres, Spain, ${ }^{4}$ Internal Medicine Service, Veterinary Teaching Hospital, Caceres, Spain, \\ ${ }^{5}$ Pathological Anatomy Service, Hospital Espírito Santo E.P.E., Évora, Portugal
}

A 2 years old dog was brought to the clinic with complains of testicular enlargement. The tissue was diffusely affected as confirmed by ultrasonographic examination, being the right testicle atrophied and the right epididymis enlarged, with loss of echotexture and presence of several anechogenic areas. The situation required the excision of the referred testicle and epididymis. Final diagnose made by histopathological analysis was primary unilateral low-grade paratesticular leiomyosarcoma. Scarce bibliography is found on this matter, with several cases reported on human, and none in dog. This case report is therefore an important milestone on the area of small animal oncology directly related to the reproductive tissue.

Keywords: dog, oncology, paratesticular, leiomyosarcoma, urogenital

\section{BACKGROUND}

Paratesticular sarcomas are mesenchymal tumors that can be originated in soft tissues, such as the spermatic chord, inguinal canal, testicular tunic or epididymis (1). In humans, the incidence of soft tissue sarcoma has been reported to be $1.8-5.0$ per 100,000 per year, with $1.5 \%$ affecting the male genital tract (2). Among paratesticular sarcomas, it has been reported in humans that the most common histological subtypes are liposarcoma, leiomyosarcoma, rhabdomyosarcoma, undifferentiated pleomorphic sarcoma and fibrosarcoma (3-5). The prognosis is usually considered poor, since recurrence and metastasis are common (6). Moreover, the mechanism and outcome of regional lymph node resection, radiotherapy and chemotherapy is reportedly unclear in the human species (6). In dogs, tumors of the testicular region are relatively common, representing more than $90 \%$ of all canine genital tract tumors (7). However, it rarely affects paratesticular structures, such as the spermatic cord, inguinal canal, testicular tunic or epididymis (1).

Different histological techniques are used to pathologic diagnosis. However, sometimes the tissue line is not obvious and other techniques are required. Indeed, immunohistochemistry (IHC) plays an important role in the diagnosis of soft tissue tumors $(8,9)$. 


\section{CASE PRESENTATION}

A 2 years old Spanish Mastiff was seen for the first time at the Veterinary Teaching Hospital of the University of Extremadura on April 2013. The complaint was scrotal enlargement starting $\sim 3$ weeks before. On scrotal palpation it was detected an apparently painless enlarged firm mass inside the right hemiscrotum with slightly increased temperature, when compared with the content of the left hemiscrotum. Physical examination also revealed parameters within normal limits, specifically temperature, mucosae, capillary retention, heart and respiratory rates, pulmonary auscultation and external lymph nodes. The size and consistency of the left testicle were apparently normal. A testicular ultrasonography was performed, major findings being: left testicle normal; right testicle atrophied; right epididymis presenting increased size $(\sim 4 \mathrm{~cm})$, loss of normal echogenicity and presence of several anechogenic areas $(<2 \mathrm{~cm})$ (Figure $\mathbf{1})$.

A presumptive diagnosis of bacterial orchitis/epididymitis was proposed and treatment was started, with anti-inflammatory Meloxicam 24-24h during 5 days $\left(0.1 \mathrm{mg} / \mathrm{kg}\right.$; Metacam ${ }^{\circledR}$, Boehringer Ingelheim, Ingelheim, Germany), and broad spectrum antibiotic Ciprofloxacin 12-12 h $\quad(20 \mathrm{mg} / \mathrm{kg}$; Ciprofloxacino Normon, Madrid, Spain). The patient returned after 11 days and ultrasonography was repeated, presenting a reduction of the testicular size with persistence of the anechogenic areas. Due to the lack of regression of the lesions, surgical removal of the affected testis was proposed and unilateral orchiectomy was scheduled. Despite recommendation for bilateral castration, the owner decided to maintain the apparently healthy left testicle. Informed consent was signed by the owner respecting all the procedures reported, as well as the publication of this case report. Hematology and most biochemical parameters were within the normal range, except for total protein which presented a slightly reduced value (5 g/dL), with normal serum albumin (Tables 1, 2). Hemicastration of the right testicle was performed on the following week being the tissue sent for histopathology analysis. On the following 4 days, anti-inflammatory and antibiotic treatment was administered at the same doses as previously.

After 10 days the dog returned to follow-up, presenting increased inflammation on the area of excision, and presence of an anechogenical cavity on the interior. Inguinal lymph nodes were ultrasonographically normal, with no evidence of metastasis. Abdominal and thoracic radiographs were also made, with no gross abnormalities detected. Anti-inflammatory was again prescribed for 5 days, and antibiotic treatment was maintained for additional 15 days, maintaining previously used doses.

The excised testicle and epididymis were fixed in 5 per cent formaldehyde in a $0.1 \mathrm{M}$ phosphate buffer ( $\mathrm{pH} 7.2$ ), processed and embedded in paraffin. For histopathological analysis, $5 \mu \mathrm{m}$ sections were stained with hematoxylin-eosin and Masson Trichrome.

Histologically, the testis presented an extensive destruction of seminiferous tubules with a certain degree of intertubular connective tissue proliferation. Spermatogenic cells showed evident signs of degeneration, ranging from cellular swelling to apoptosis. The testicular parenchyma presented multiple inflammatory foci, consisting mainly of monocytes, lymphocytes and lesser degree plasma cells.

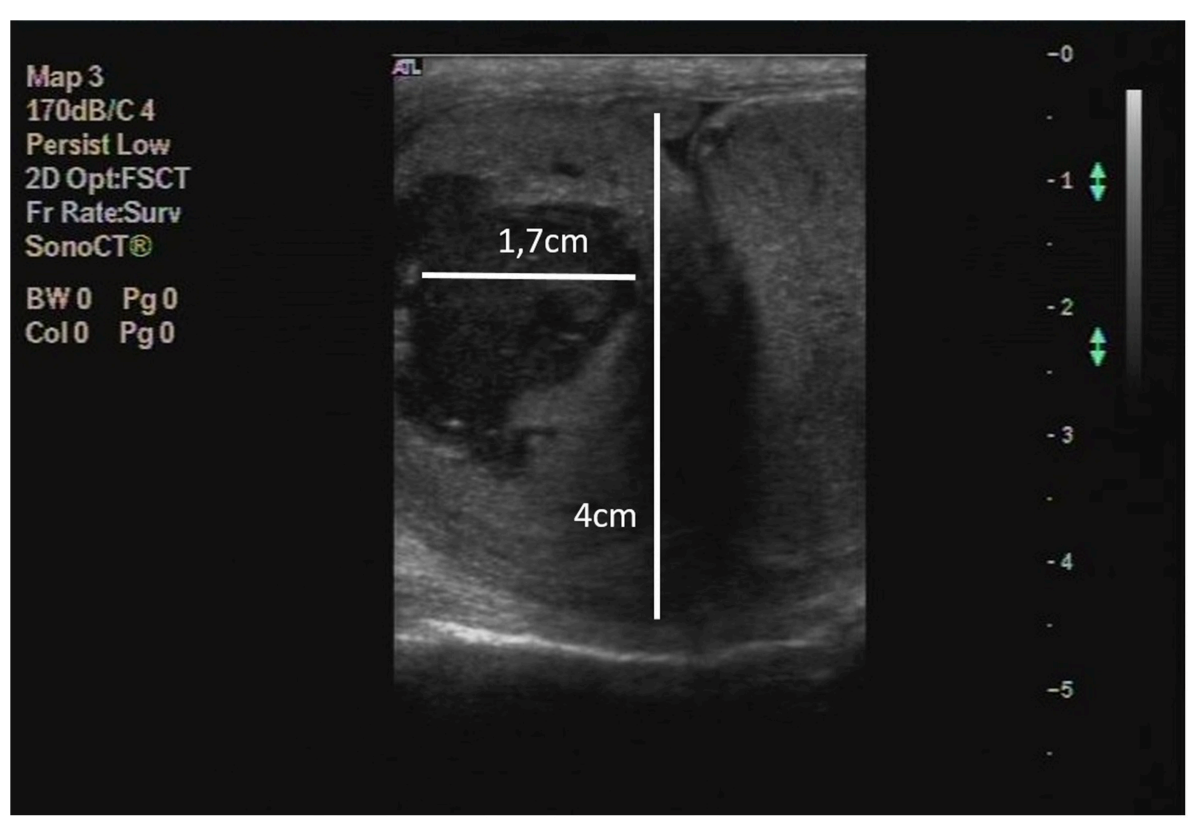

FIGURE 1 | Testicle and epididymis, dog. Diagnostic ultrasonography of the epididymis (4 cm) with indication of one of the anechogenic areas (1.7 cm). 
TABLE 1 | Preoperative hematology.

\begin{tabular}{lc}
\hline Parameter & Data of the animal \\
\hline Red blood cells $\left(/ \mathrm{mm}^{3}\right)$ & $7,000,000$ \\
Hematocrit $(\%)$ & 50.2 \\
Hemoglobin $(\mathrm{g} / \mathrm{dL})$ & 17.3 \\
MCV (fl) & 71.7 \\
MCH $(\mathrm{pg})$ & 24.7 \\
MCHC (g/dL) & 34.5 \\
White blood cells $\left(/ \mathrm{mm}^{3}\right)$ & 10,340 \\
Neutrophils & 6,850 \\
Eosinophils & 770 \\
Basophils & 0 \\
Lymphocytes & 2,170 \\
Monocytes & 550 \\
Platelet count & 236,000
\end{tabular}

TABLE 2 | Preoperative biochemistry.

\begin{tabular}{lc}
\hline Parameter & Data of the animal \\
\hline Urea $(\mathrm{mg} / \mathrm{dL})$ & 26.9 \\
Creatinine $(\mathrm{mg} / \mathrm{dL})$ & 0.8 \\
ALT $(\mathrm{Ul} / \mathrm{L})$ & 19 \\
Total bilirubin $(\mathrm{mg} / \mathrm{dL})$ & 0.3 \\
Total protein $(\mathrm{g} / \mathrm{dL})$ & 5 \\
Albumin $(\mathrm{g} / \mathrm{dL})$ & 3.15
\end{tabular}

Surrounding the testis, an abundant proliferation of loose connective tissue was shown, formed by fusocellular cells with slight atypia, without necrosis and with few atypical mitosis (1/10 HPF) (Figure 2a). This cell proliferation extended to the epididymis, causing a compressive phenomenon in its structures, which leads to two specific pathological changes, the disappearance of ducts and the dilation of the remaining ones by an increase of pressure, changing its cylindrical pseudostratified epithelium to an epithelium simple plane. In this tissue there were inflammatory cellular accumulations similar to those presented in the testis, although in a much lower number, with sketches of granulomas with giant cells, compatible with chronic inflammatory processes.

In order to classify the lesions, immunohistochemical study was performed using an automated slide stainer (Benchmark Ultra, Ventana $\left.{ }^{\circledR}\right)$. Sections were immunostained using vimentin, actin, desmin, CD34, AE1/AE3 and Ki67 primary polyclonal antibodies (Roche ${ }^{\circledR}$ ) according manufacturer's recommendations (Table 3). Bound Antibodies were visualized using avidin-biotin-peroxidase complex $(\mathrm{ABC})$ technique and diaminobenzidine. Immunohistochemical study of cell proliferation showed positivity to Actin (Figure 2b), Ki67 (5-10\%) (Figure 2c) and Vimentin (Figure 2d), and negativity to Desmin, CD34 and AE1/AE3, which indicates a low-grade leiomyosarcoma, according to recent studies (8).
TABLE 3 | Details of primary antibodies.

\begin{tabular}{llll}
\hline Antibody & Clon & $\begin{array}{l}\text { Retrieval } \\
\text { treatment }\end{array}$ & Incubation \\
\hline Vimentin & V9 & $\begin{array}{l}\text { Cell conditioning } \\
\text { solution } \\
\text { CC1/32 min }\end{array}$ & $16 \mathrm{~min}$ \\
& & CC1/8 min & $104 \mathrm{~min}$ \\
Actin & 1A4 & CC1/40 min & $16 \mathrm{~min}$ \\
Desmin & DE-R-11 & CC1/32 min & $16 \mathrm{~min}$ \\
CD34 & QBEnd/10 & Protease $4 \mathrm{~min}+$ & $8 \mathrm{~min}$ \\
KI-67 & PCK26 & CC1/8 min & $16 \mathrm{~min}$ \\
\hline
\end{tabular}

After 6 months from the surgery, the dog was present for clinical examination, presenting no alterations in the scrotum or in the left testicle, as well as in other structures of the abdominal cavity, assessed by ultrasonography. The owner was asked to return annually but it was not possible to continue follow-up of the animal.

\section{DISCUSSION}

Paratesticular tumors are a rare condition in humans (1) and in dogs $(7,10)$. The proximity and communication between the structures in the testis and paratestis result in a variety of tumors and tumor-like structures that present a diagnostic challenge due to their morphologic overlap and rarity (11). This heterologous group of tumors can follow different clinical courses, being histopathological subtype and tumor grade the most important features to determine prognosis (12). In the present case, the low-grade sarcoma with muscle differentiation found could be expected to have a lower risk of metastization, as confirmed in human spermatic cord sarcomas (13).

A retrospective study made in 2016 evaluated the most common tumor diagnoses in dogs in Switzerland between 1995 and 2008, comprising 63,214 neoplasic lesions, with soft tissues occupying the second higher risk after mammary gland, although no reference to paratesticular tumors was made (14). Extratesticular tumors have been found in previously neutered dogs, in the spermatic cord and within the scrotal tunic, or even arising from the prescrotal incision site (10). However, these neoplasms consisted mainly on Sertoli or interstitial cell tumors, suggesting trauma, embryological ectopic testicular tissue, polyorchism or testicular tissue transplantation during surgery (10).

Primary malignant neoplasia of the epididymis has been considered a very rare condition in humans (15). Although more frequent in adults, epididymal tumors have been reported in young boys (15) which occurred similarly in the present case, since the veterinary patient was 2 years old large breed dog. Nevertheless, paratesticular sarcomas in humans have been reported to occur in all age groups, typically presenting as slow growing, painless, firm scrotal or growing masses, ranging in size from small, barely palpable lesions to very 


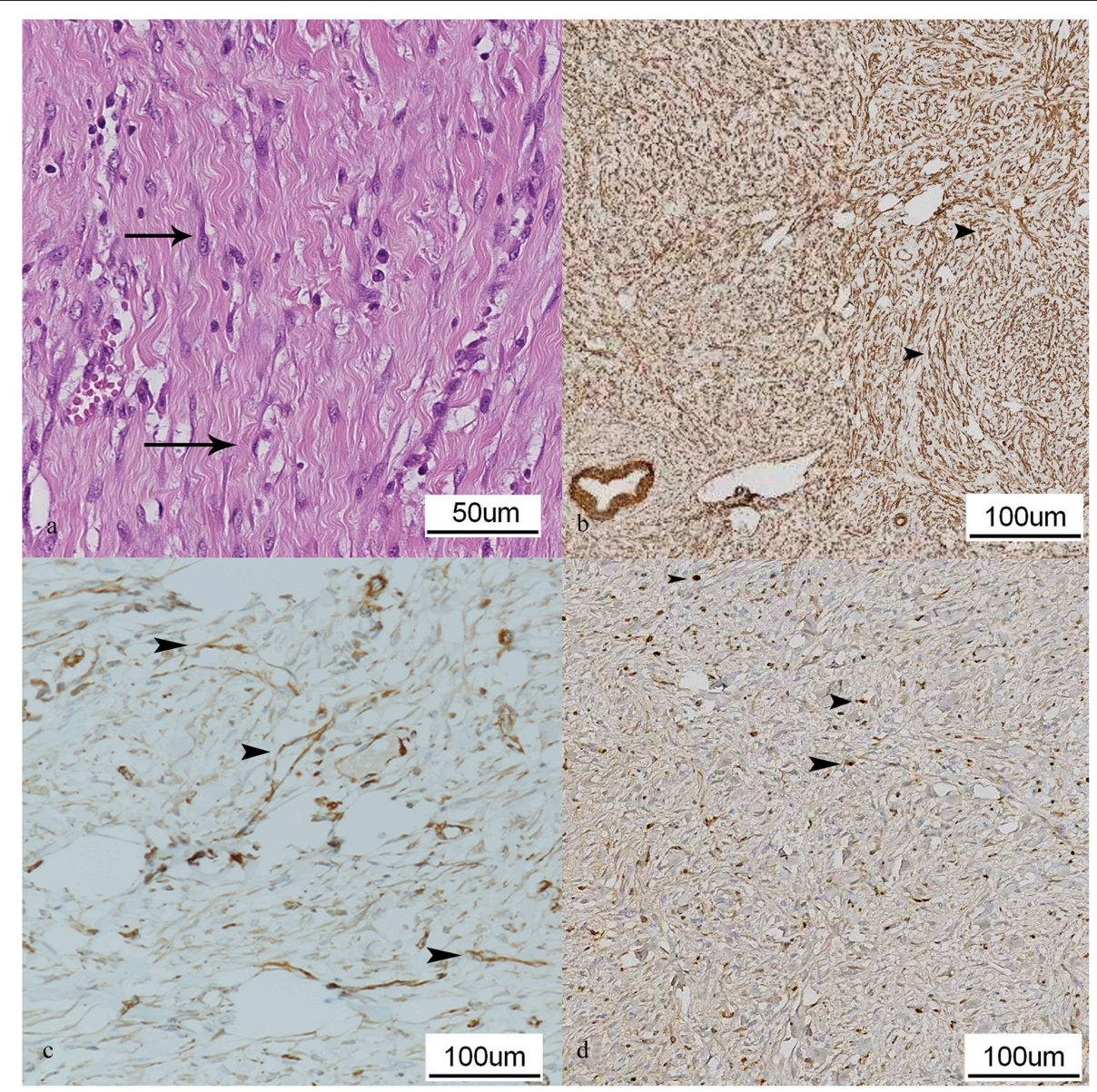

FIGURE 2 | Paratesticular tissue, dog. (a) Histopathological study of the sample. Proliferation of loose connective tissue composed of fusocellular cells with slight atypia (arrows). Hematoxylin and eosin (HE). (b) Actin immunohistochemical stain. This stain highlights the presence of numerous cells which show a fusiform morphology (arrowheads). (c) Ki67 immunohistochemical stain of the lesion. Presence of fusiform cells expressing this marker, indicating cell proliferation (arrowheads). (d) Vimentin immunohistochemical stain in which it is observed several immunolabeled cells disposed with diffuse pattern and morphology that points to a mesenchymal origin (arrowheads).

large masses (1). In the present case, the physical exam was also compatible with the final diagnose of paratesticular tumor. In dogs, mixed germ cell-stromal tumors account for $7 \%$ of testicular tumors. Other less common tumors include hemangioma, granulosa cell, sarcoma, embryonal carcinoma, gonadoblastoma and lymphoma (7). Papillary carcinoma of the epididymis has been described in dog, as well as mesenchymal tumors, such as fibroma/fibrosarcoma and leiomyoma/leiomyosarcoma (16), such as on the present case. The sparse bibliography found on this matter available and the small number of published cases provide few information on prognosis, which, to the author's knowledge, was apparently favorable.

\section{DATA AVAILABILITY}

All datasets generated for this study are included in the manuscript and/or the supplementary files.

\section{AUTHOR CONTRIBUTIONS}

CBS and LGG contributed to the writing of the manuscript and literature review. LGG, JCG, and CP contributed to the histopathological study, interpretation and description of the imaging finding. CBS, CO-F, PM-M, and FPV were responsible for the surgery and follow-up of the case. FDC was responsible for the ultrasonography imaging.

\section{FUNDING}

Ministerio de Economía y Competitividad-FEDER, Madrid, Spain, grants AGL2017-83149-R, Junta de Extremadura FEDER (IB16030 and GR18008). IP for the grants FPV. Ministerio de Educación, Cultura y Deporte, Madrid, Spain, grant FPU13/03991 for PM-M. The funders had no role in study design, data collection and analysis, decision to publish, or preparation of the manuscript. 


\section{REFERENCES}

1. Dafydd D, Messiou C, Thway K, Strauss DC, Nicol DL, Moskovic E. Paratesticular sarcoma: typical presentation, imaging features and clinical challenges. Urology. (2017) 100:163-8. doi: 10.1016/j.urology.2016. 09.005

2. Wibmer C, Leithner A, Zielonke N, Sperl M, Windhager R. Increasing incidence rates of soft tissue sarcomas? A population-based epidemiologic study and literature review. Ann Oncol. (2010) 21:1106-11. doi: 10.1093/annonc/mdp415

3. Lioe TF, Biggart JD. Tumours of the spermatic cord and paratesticular tissue. A clinicopathological study. Br J Urol. (1993) 71:600-6. doi: 10.1111/j.1464-410X.1993.tb16033.x

4. Soosay GN, Parkinson MC, Paradinas J, Fisher C. Paratesticular sarcomas revisited: a review of cases in the British Testicular Tumour Panel and Registry. Br J Urol. (1996) 77:143-6. doi: 10.1046/j.1464-410X.1996. 84925.x

5. Khoubehi B, Mishra V, Ali M, Motiwala H, Karim O. Adult paratesticular tumours. $\mathrm{Br} J$ Urol Int. (2002) 90:707-15. doi: 10.1046/j.1464-410X.2002.02992.x

6. Unlu Y, Huq GE, Ozyalvacli G, Zengin M, Koca SB, Yucetas U, et al. Paratesticular sarcomas: a report of seven cases. Oncol Lett. (2015) 9:308-12. doi: 10.3892/ol.2014.2629

7. North S, Banks T, Straw R. Tumours of the urogenital tract. In: North S, Banks T, Straw R, editors. Small Animal Oncology, an Introduction. Edinburgh; London; New York, NY; Oxford; Philadelphia, PA; St. Louis; Sydney; Toronto, ON: Elsevier Saunders (2009). p. 151-71.

8. Wei S, Henderson-Jackson E, Quian X, Bui MM. Soft tissue tumor immunohistochemistry update: illustrative examples of diagnostic pearls to avoid pitfalls. Arch Pathol Lab Med. (2017) 141:1072-91. doi: 10.5858/arpa.2016-0417-RA

9. Parham DM. Immunohistochemical markers of soft tissue tumors: pathologic diagnosis, genetic contributions, and therapeutic options. Anal Chem Insights. (2015) 10:1-10 doi: 10.4137/ACI.S32730
10. Doxsee AL, Yager JA, Best SJ, Foster RA. Extratesticular interstitial and Sertoli cell tumors in previously neutered dogs and cats: a report of 17 cases. Can Vet J. (2006) 47:763-6.

11. Amin MB. Selected other problematic testicular and paratesticular lesions: rete testis neoplasms and pseudotumors, mesothelial lesions and secondary tumors. Mod Pathol. (2005) 18 (Suppl. 2):S131-45. doi: 10.1038/modpathol.3800314

12. Kucuk U, Bayol U, Pala EE, Akman O, Divrik RT. Paratesticular sarcomas: our case series. Turk J Urol. (2013) 39:84-9. doi: 10.5152/tud.2013.017

13. Radaelli S, Desai A, Hodson J, Colombo C, Roberts K, Gourevitch D, et al. Prognostic factors and outcome of spermatic cord sarcoma. Ann Surg Oncol. (2014) 21:3557-63. doi: 10.1245/s10434-014-3751-1

14. Gruntzig K, Graf R, Boo G, Guscetti F, Hassig M, Axhausen KW, et al. Swiss Canine Cancer Registry 1955-2008: occurrence of the most common tumour diagnoses and influence of age, breed, body size, sex and neutering status on tumour development. J Comp Pathol. (2016) 155:156-70. doi: 10.1016/j.jcpa.2016.05.011

15. McCormack M. Bilateral fibrosarcoma of the epididymis. J Clin Pathol. (1975) 28:576-9. doi: $10.1136 /$ jcp.28.7.576

16. McEntee K. Scrotum, spermatic cord and testis. In: Reproductive Pathology of Domestic Mammals. San Diego, CA: Academic Press Inc. (1990). p. 279-306.

Conflict of Interest Statement: The authors declare that the research was conducted in the absence of any commercial or financial relationships that could be construed as a potential conflict of interest.

Copyright (C) 2019 Balao da Silva, Gómez Gordo, Cuesta Gerveno, Ortega-Ferrusola, Martín-Muñoz, Duque Carrasco, Parejo and Peña Vega. This is an open-access article distributed under the terms of the Creative Commons Attribution License (CC $B Y)$. The use, distribution or reproduction in other forums is permitted, provided the original author(s) and the copyright owner(s) are credited and that the original publication in this journal is cited, in accordance with accepted academic practice. No use, distribution or reproduction is permitted which does not comply with these terms. 